\title{
Microbiological and chemical characteristics of traditional ewe's milk cheese from Mariovo region
}

\author{
doi: $10.15567 /$ mljekarstvo.2014.0307 \\ Vesna Levkov ${ }^{1 *}$, Sonja Srbinovska², Natasha Gjorgovska \\ ${ }^{1}$ Department of Nutrition and Food Products Processing, Institute of Animal Science, Ss Cyril and \\ Methodius University, Blvd. Ilinden 92a, 1000 Skopje, Macedonia \\ ${ }^{2}$ Department of Livestock, Faculty of Agricultural Science and Food, Ss Cyril and Methodius University, \\ Blvd. Aleksandar Makedonski bb., 1000 Skopje, Macedonia \\ Received - Prispjelo: 13.11.2013. \\ Accepted - Prihvaćeno: 15.07.2014.
}

\begin{abstract}
Traditional beaten cheese was manufactured in two different farms located in Mariovo region (southern Macedonia) during the summer period using raw ewe's milk. High counts of all microbial groups were found in ewe's milk (aerobic mesophilic bacteria $5.22 \times 10^{6}-1.25 \times 10^{7} \mathrm{CFU} \cdot \mathrm{mL}^{-1}$, presumptive lactococci $3.30 \times 10^{6}-1.34 \times 10^{7} \mathrm{CFU} \cdot \mathrm{mL}^{-1}$, presumptive lactobacilli $1.93 \times 10^{6}-2.63 \times 10^{6}$ $\mathrm{CFU} \cdot \mathrm{mL}^{-1}$, coliform bacteria $2.35 \times 10^{5}-6.30 \times 10^{5} \mathrm{CFU} \cdot \mathrm{mL}^{-1}$ and yeasts $\left.1.24 \times 10^{4}-2.40 \times 10^{4} \mathrm{CFU} \cdot \mathrm{mL}^{-1}\right)$. The lactic acid bacteria prevailed during manufacturing and ripening of the ewe's cheese. All investigated groups reached their maximum value during the dry ripening period and then gradually decline during salting and brining. A total of 240 isolates were taken from all stages of manufacturing and ripening. The prevailing species were Lactococcus lactis ssp. lactis (35\%), Pediococcus sp. (16.7\%), Leuconostoc sp. (1 \%), Lactobacillus paracasei ssp. paracasei (22.5\%), L. plantarum (15.8\%) and L. brevis (9.17\%). After 45 days of ripening the content of $\mathrm{NaCl}(6.1 \pm 0.8 \%$ and $6.6 \pm 0.1 \%)$ and salt to moisture $(\mathrm{S} / \mathrm{M})$ ratio $(15.6 \pm 1.4 \%$ and $17.3 \pm 0.3 \%)$ in both cheeses was very high. The values of $\mathrm{pH}$ were 5.13-5.22. The main factors influencing the microbiological counts were $\mathrm{NaCl}$ and $\mathrm{S} / \mathrm{M}$ content, and a strong correlation $(\mathrm{p}<0.05)$ was noticed between these two factors and the counts of the investigated microbial groups.
\end{abstract}

Key words: beaten cheese, microflora composition, microflora dynamics, traditional ewe's cheese, Mariovo

\section{Introduction}

Interest in traditional cheeses available on markets is growing since they possess a characteristic flavour and aroma, which cannot be found in industrially produced cheeses (Garabal, 2007). Traditional cheeses are considered as unique ecosystems which contain different types of microorganisms with positive influence on cheese ripening and sensorial characteristics (Beresford and Williams, 2004). The production of different cheese varieties such as white brined cheese, beaten cheese and Kashkaval in traditional manner is still present in rural areas of
Macedonia. Beaten cheese manufacture is economically important trait in rural district of Mariovo region. This cheese variety is made in small farms or households from raw ewe's milk without addition of starter culture. The beaten cheese produced in such manner compared to the industrial variety is characterized by more specific sensory features.

The characteristics of the region where the cheese was produced, the sanitary conditions during production, the stage of lactation and the nutrition method influenced the milk and cheese characteristics (Micari et al., 2007). 
The relatively poor hygienic conditions during milking and cheese making and the inappropriate conditions of their storage negatively influenced the cheese quality (Özdemir et al., 2010). The interactions between seasonal changes, the nutrition and physiological changes influenced the milk characteristics and consequently also the cheese quality. The season of lambing and the stage of lactation considerably influence milk composition. The lower milk quality results in lower content of casein, milk fats, calcium and phosphorus (Sevi et al. 2004).

The region of Mariovo is situated in southern part of Macedonia, close to the border with Greece. It is surrounded by high mountains and represents a specific natural area. The region has a diverse flora, due to the specific climate, as well as geologic, geomorphologic and pedologic features (Matevski and Kostadinovski, 1998).

There is a very small amount of available information on composition and microbiological characteristics of the ewe's milk beaten cheese produced in the traditional manner from Mariovo region. The first data for physico-chemical and rheological characteristics of beaten cheese from Mariovo were given by Kapac-Parkačeva et al. (1974). The preliminary study of microbiological characteristics of the beaten cheese was performed by Levkov and Kakurinov (2011).

The aim of present study was to investigate representative groups of microorganisms during the beaten cheese manufacturing and ripening, as well as to estimate the influence of main physico-chemical factors on the dynamics and presence of investigated microorganisms. The isolation and determination of significant lactic acid bacteria (LAB) from all stages of cheese production was also object of this study. This study can be considered as a first attempt to obtain autochthonous starter cultures in order to keep the authentic features of Mariovo's beaten cheese such as appearance, taste and aroma.

This study will contribute to the establishment of microbiological quality standards for beaten cheese and to provide scientific basis for understanding of beaten cheese ripening process. Such basis is necessary to improve the farmhouse procedures and sanitary conditions in order to obtain safe and healthy products.

\section{Materials and methods}

\section{Cheese manufacture and sampling}

Microbiological analyses were conducted on traditionally produced beaten cheese samples originating from two different farms (batches $\mathrm{A}$ and $\mathrm{B}$ ) in village Peshtani, Mariovo region. t Samples of milk, curd, cheese over dry ripening process $\left(2^{\text {nd }}\right.$ day of ripening), dry salting ( $5^{\text {th }}$ day of ripening) and 10,30 and 45 days of brine ripening were analysed during the summer period. The samples were taken within three different cheese production campaigns in each farmhouse. The cheese production technology was similar at both farmhouses. Microbiological analyses were carried out at least in duplicate for each batch and the values were averaged.

Raw ewe's milk from both, evening and morning, milking was used to manufacture the cheese. The curdling was performed with liquid commercial rennet for 45-50 min without heating the milk. The curd was throughly stirred with a wooden tool (3 series of 40-50 times each) and left to settle down for $15 \mathrm{~min}$. Subsequently, hot water $\left(80-90^{\circ} \mathrm{C}\right)$ was added into the vat under gentle stirring and the curd was left to settle down for 5-10 min. After the curd temperature had reached approximately $46^{\circ} \mathrm{C}$, whey was removed and the curd was pressed by hand and transferred into a cheese cloth which was fastened and hung to drain for $24 \mathrm{~h}$ at room temperature $\left(\sim 25^{\circ} \mathrm{C}\right)$. The next day the curd was covered with cheese cloth and left for dry ripening for 1-2 days (depending on ambient temperature) in the same environment. Then the cheese was cut into rectangular slices approximately $5-7 \mathrm{~cm}$ thick and salted on the surface with coarse-grained salt. Salted slices were transferred into the tins and left in the same room for 1-2 days, depending on the ambient temperature. Finally, the tins containing cheese slices were filled with brine (22\% salinity) and left to brine ripening for 45 days in the same room.

Samples were taken under sterile conditions, placed into plastic sterile dishes and kept under refrigeration until analysis. Microbiological analyses were preformed within $24 \mathrm{~h}$ after the sampling.

\section{Microbiological analysis}

Aliquot of $10 \mathrm{~mL}$ of milk or $10 \mathrm{~g}$ of cheese was homogenized with $90 \mathrm{ml}$ of sterile $2 \%$ sodium-citrate 
solution. Decimal dilution was made with sterile physiological solution. Microbiological analyses were performed by a plate pouring method whereby the aerobe mesophilic bacteria were counted on Plate count agar (BioMérieux, Marcy l'Etoile, France) after $48 \mathrm{~h}$ of incubation at $30{ }^{\circ} \mathrm{C}$; Mesophilic lactic acid bacteria (LAB) and Streptococci were counted on M-17 agar (Biolife, Milano, Italy) after $48 \mathrm{~h}$ of incubation at $30^{\circ} \mathrm{C}$ and MRS agar (Biolife) was used for lactobacilli enumeration by incubating at $30{ }^{\circ} \mathrm{C}$ for $72 \mathrm{~h}$ under anaerobic conditions (GENbag anaer, BioMérieux). Coliform bacteria were counted on ENDO agar (Biolife) after $24 \mathrm{~h}$ of incubation at $37^{\circ} \mathrm{C}$; while YGC agar (Merck, Darmstadt, Germany) was used for yeast determination by incubating the samples at $25^{\circ} \mathrm{C}$ for 5 days.

\section{Identification of isolates}

Lactic acid bacteria were obtained by random picking per milk and cheese sample from M-17 and MRS agar plates. Isolates were purified by consecutive subculturing on M-17 and MRS agar. Purified isolates were stored in M-17 broth and MRS broth being subcultured at intervals of every month or two.

A total of 240 isolates were determined to genus level by their morphological and physiological characteristics according to criteria of Bergey's manual of determinative bacteriology (Holt et al., 1994). Isolates assigned as Gram-positive, catalasenegative homofermentative cocci in pares or short chain, which grew at $15^{\circ} \mathrm{C}$ but not at $45^{\circ} \mathrm{C}$ in presence of $6.0 \% \mathrm{NaCl}$ were considered as mesophillic lactococci. Gram-positive, catalase-negative cocci grouped in tetrads, in presence of $4.0 \%$ and $7.0 \%$ $\mathrm{NaCl}$ were considered as Pediococcus. Gram-positive, catalase-negative rods, individually or in pars, which grew at $15^{\circ} \mathrm{C}$ and $30{ }^{\circ} \mathrm{C}$ were considered as Lactobacillus. Finally the fermentative characteristics of representative samples were analysed by using API 50CHL system (bioMérieux).

\section{Physicochemical analyses}

Cheese samples were analysed for $\mathrm{pH}$ by a $\mathrm{pH}$ meter (HANNA Instruments, Kehl am Rhein, Germany); titratable acidity according to Soxlet-Henkel method (1963); water content according to Kosikowski and Mistry (1997); dry matter by drying
(ISO 5534:2004) and the content of $\mathrm{NaCl}$ by modified Volhard test (Kosikowski and Mistry, 1997). Salt to moisture ratio (S/M) was calculated according to equation 1 as follows:

$$
S I M=\frac{C S}{C M} \times 100
$$

where $\mathrm{CS}$ is $\mathrm{NaCl}$ content (\%) and $\mathrm{CM}$ is moisture content $(\%)$ in cheese.

\section{Statistical analyses}

Statistical analyses were conducted using t-test and Pearson coefficient of correlation between the counts of microbiological groups in milk and cheese samples and physicochemical parameters. The analyses were performed using the software package Statgraph 3.0 (Statistical Graphics, Warrenton, Virginia, USA).

\section{Results and discussion}

The physico-chemical characteristics of beaten cheese during manufacturing and ripening are presented in Table 1.

On the $2^{\text {nd }}$ day of ripening $\mathrm{pH}$ significantly decreased, which was most probably a result of lactic acid production by LAB. Similarly, variations in $\mathrm{pH}$ values between batches most probably originated from acidifying activities of LAB microflora present in cheese (Prodromou et al., 2001). The gradual increase in $\mathrm{pH}$ value during cheese brine ripening $(10,30,45$ days of ripening) might be a result of yeast metabolic activity which use lactic acid as a source of carbon, or a result of great amounts of alkaline compounds released during proteolytic activities (Volken de Souza et al., 2003). As a result of diverse metabolic activity titratable acidity gradually increased during cheese ripening (Dubrova Mateva et al., 2008). Somewhat lower value of titratable acidity was recorded in batch $\mathrm{A}(\mathrm{p}<0.05)$. Although a great amount of lactose was excreting, lactobacilli most probably utilized the residual lactose in cheese and contributed to titratable acidity increase in cheese batch B (Arenas et al., 2004).

Due to syneresis, cheese moisture gradually decreased during the production process as noted by Terzic-Vidojevic et al. (2007). The levels of cheese moisture and cheese dry matter between two batches of beaten cheese were comparable, with 
Table 1. Changes in the physico-chemical parameters during manufacturing and ripening of beaten cheese

\begin{tabular}{|c|c|c|c|c|c|c|c|c|}
\hline \multirow{2}{*}{$\begin{array}{c}\text { Para- } \\
\text { meters }\end{array}$} & \multirow{2}{*}{ Farm } & \multirow{2}{*}{ Milk } & \multirow{2}{*}{ Curd } & \multicolumn{5}{|c|}{ Days of ripening } \\
\hline & & & & 2 & 5 & 10 & 30 & 45 \\
\hline \multirow{2}{*}{$\mathrm{pH}$} & A & $6.54 \pm 0.03$ & $6.52 \pm 0.04$ & $5.11 \pm 0.02$ & $5.09 \pm 0.03$ & $5.15 \pm 0.07$ & $5.17 \pm 0.03$ & $5.22 \pm 0.06$ \\
\hline & B & $6.56 \pm 0.03$ & $6.54 \pm 0.01$ & $5.17 \pm 0.04$ & $5.08 \pm 0.05$ & $5.13 \pm 0.03$ & $5.10 \pm 0.12$ & $5.13 \pm 0.06$ \\
\hline \multirow{2}{*}{$\begin{array}{c}\text { Titratable } \\
\text { acidity } \\
{\left[\mathrm{SH}^{\circ}\right]}\end{array}$} & $\mathrm{A}$ & $9.33 \pm 0.31$ & $16.93 \pm 0.46$ & $62.13 \pm 2.01$ & $65.07 \pm 3.95$ & $66.23 \pm 3.16$ & $68.27 \pm 1.22$ & $76.27 \pm 2.01$ \\
\hline & B & $9.20 \pm 0.20$ & $16.40 \pm 0.80$ & $75.20 \pm 4.87^{*}$ & $79.20 \pm 1.39 *$ & $81.87 \pm 2.57^{*}$ & $85.33 \pm 3.33^{*}$ & $78.93 \pm 4.89$ \\
\hline \multirow{2}{*}{$\begin{array}{c}\text { Dry mat- } \\
\text { ter }[\%]\end{array}$} & A & $18.9 \pm 3.1$ & $26.9 \pm 1.9$ & $54.5 \pm 2.3$ & $62.1 \pm 1.2$ & $60.9 \pm 1.0$ & $58.7 \pm 6.5$ & $61.1 \pm 1.8$ \\
\hline & B & $18.3 \pm 0.3$ & $26.9 \pm 3.7$ & $53.6 \pm 1.5$ & $66.6 \pm 3.2^{*}$ & $62.1 \pm 0.9$ & $61.6 \pm 1.0$ & $61.6 \pm 1.2$ \\
\hline \multirow{2}{*}{$\begin{array}{c}\text { Water } \\
\text { content } \\
{[\%]}\end{array}$} & A & - & $73.1 \pm 1.9$ & $45.5 \pm 2.3$ & $37.9 \pm 1.2^{*}$ & $39.1 \pm 1.0$ & $37.9 \pm 0.7$ & $38.9 \pm 1.8$ \\
\hline & $\mathrm{B}$ & - & $73.1 \pm 3.7$ & $46.4 \pm 1.5$ & $33.4 \pm 3.2$ & $37.9 \pm 1.0$ & $38.4 \pm 1.0$ & $38.4 \pm 1.2$ \\
\hline \multirow{2}{*}{$\mathrm{NaCl}[\%]$} & A & - & - & - & $3.8 \pm 1.1$ & $6.0 \pm 0.6$ & $5.6 \pm 0.3$ & $6.1 \pm 0.8$ \\
\hline & B & - & - & - & $3.8 \pm 0.1$ & $5.0 \pm 0.6$ & $7.1 \pm 0.2^{*}$ & $6.6 \pm 0.1$ \\
\hline \multirow{2}{*}{$\mathrm{S} / \mathrm{M}[\%]$} & $\mathrm{A}$ & - & - & - & $9.9 \pm 2.8$ & $15.4 \pm 1.4$ & $14.8 \pm 1.0$ & $15.6 \pm 1.4$ \\
\hline & $\mathrm{B}$ & - & - & - & $11.3 \pm 1.2$ & $14.8 \pm 2.0$ & $18.6 \pm 0.6^{*}$ & $17.3 \pm 0.3$ \\
\hline
\end{tabular}

${ }^{*} \mathrm{p}<0.05$

Titratable acidity given in Soxlet-Henkel degrees $\left({ }^{\circ} \mathrm{SH}\right)$

certain variations at $5^{\text {th }}$ day of ripening (dry salting). These variations were statistically significant $(\mathrm{p}<0.05)$ and most probably occurred because the salting of cheeses was carried out manually, without precise quantity. The results obtained in this study confirmed earlier findings of Tarakci et al. (2004) considering cheese dry salting influence on the increase in cheese dry matter.

The relatively poor sanitary conditions and the primitive production technology are the main reasons why high quantity of $\mathrm{NaCl}$ is applied by manufactures. The high quantity of $\mathrm{NaCl}$ in beaten cheese is a result of combined method of salting (dry salting and brining). Such salt content induces a hard cheese consistence, which, in turn allows easier cheese maintenance and long lasting (Dubrova Mateva et al., 2008). Both batches of investigated beaten cheese samples contained grater amount of $\mathrm{NaCl}$ in comparison to traditional Italian cheeses (Coda et al., 2006) or to white brined cheeses (TerzicVidojevic et al., 2007; Radulović et al., 2011). During cheese ripening, the content of $\mathrm{NaCl}$ gradually increased as a result of salt diffusion, which in turn depends on cheese size and format as well as on size and quantity of cheese fat globules. Also, hydration of casein micelles might interfere with the salt diffusion in cheese (Guinee and Fox, 2004).
The variations of salt content between batch $\mathrm{A}$ and B were statistically significant $(p<0.05)$ on $30^{\text {th }}$ day of ripening as a result of unequal quantity of salt addition during dry salting and brine ripening.

The high content of salt in moisture (S/M) characterised both batches of analysed beaten cheese. There were statistically significant variations which occured on $30^{\text {th }}$ day of ripening since there was no standardized technology of salting during cheese production. Such differences were also noticed in Genestoso cheese (Arenas et al., 2004). In comparison to the beaten cheese, traditional ewe's milk cheeses contained lower percentage of salt in moisture (Nikolaou et al., 2002), while the Manura cheese showed the similar levels (Gerasi et al., 2003).

The evolution of investigated microbial group counts during the manufacturing and ripening of beaten cheese are shown in Figures 1-5. The counts of aerobic mesophilic bacteria obtained from both batches of beaten cheese were in correspondence to results observed by testing other traditional cheeses (Sevi et al., 2004; Alonso-Calleja et al., 2002; Hatzikamari et al., 1999). The high counts of aerobic mesophilic bacteria (Figure 1) were found in raw ewe's milk used for manufacturing of both batches. This is characteristic for raw ewe's milk produced 
in Macedonia (Talevski et al., 2009), but the high counts of aerobic mesophilic bacteria have also been found in the ewe's milk which originated from other regions (Arenas et al., 2004; Pešić-Mikulec and Jovanović, 2005). The obtained results indicate the necessity of improving ewe's milk quality by enhancing the sanitary conditions during milking and milk handling. After the curdling, the number of aerobic mesophilic bacteria tends to increase, as a result of their multiplication and physical entrapment (Hatzikamari et al., 1999). The mesophilic aerobic bacteria reached their maximum values at $2^{\text {nd }}$ day of ripening which was in accordance with studies of Psoni et al. (2003) and Volken de Souza et al. (2003). The high count of aerobic mesophilic bacteria in beaten cheese could have been affected by the season and the ambient temperature during ripening (Bonetta et al., 2008). The number of aerobic mesophilic bacteria decreased more rapidly at the $10^{\text {th }}$ day of ripening and declined gradually until $45^{\text {th }}$ day of ripening. The negative coefficients of correlation between content of $\mathrm{NaCl}, \mathrm{S} / \mathrm{M}$ and aerobic mesophilic counts $(r=-0.84$ and $r=-0.80, p<0.01)$ suggest the inhibitory effect of high salt content and salt in moisture. The negative coefficient of correlation between $\mathrm{pH}$ and the investigated group of bacteria $(r=-0.61 \mathrm{p}<0.01)$ might indicate the possible adaptation of microorganisms to lower values of $\mathrm{pH}$ in cheese.

The significance of LAB during cheese production was confirmed by several authors (Nikolaou et al., 2002; Alonso-Calleja et al., 2002). According to Wouters et al. (2002), LAB in association with rennet enzymes might convert casein micelles into peptides and amino acids

The enzymes present in cocci and rod shaped lactic acid bacteria are involved in conversion of amino acids and lipids into aldehydes, ketones, esters, alcohols and sulfur contained compounds (Skeie and Ardö, 2000). In this manner they contribute to cheese ripening and development of cheese taste and aroma (Fox et al., 2000). The traditional cheeses contain original microflora (Beresford et al., 2001) which evolved during ripening as a result of nutritive and environmental changes in cheese (Williams et

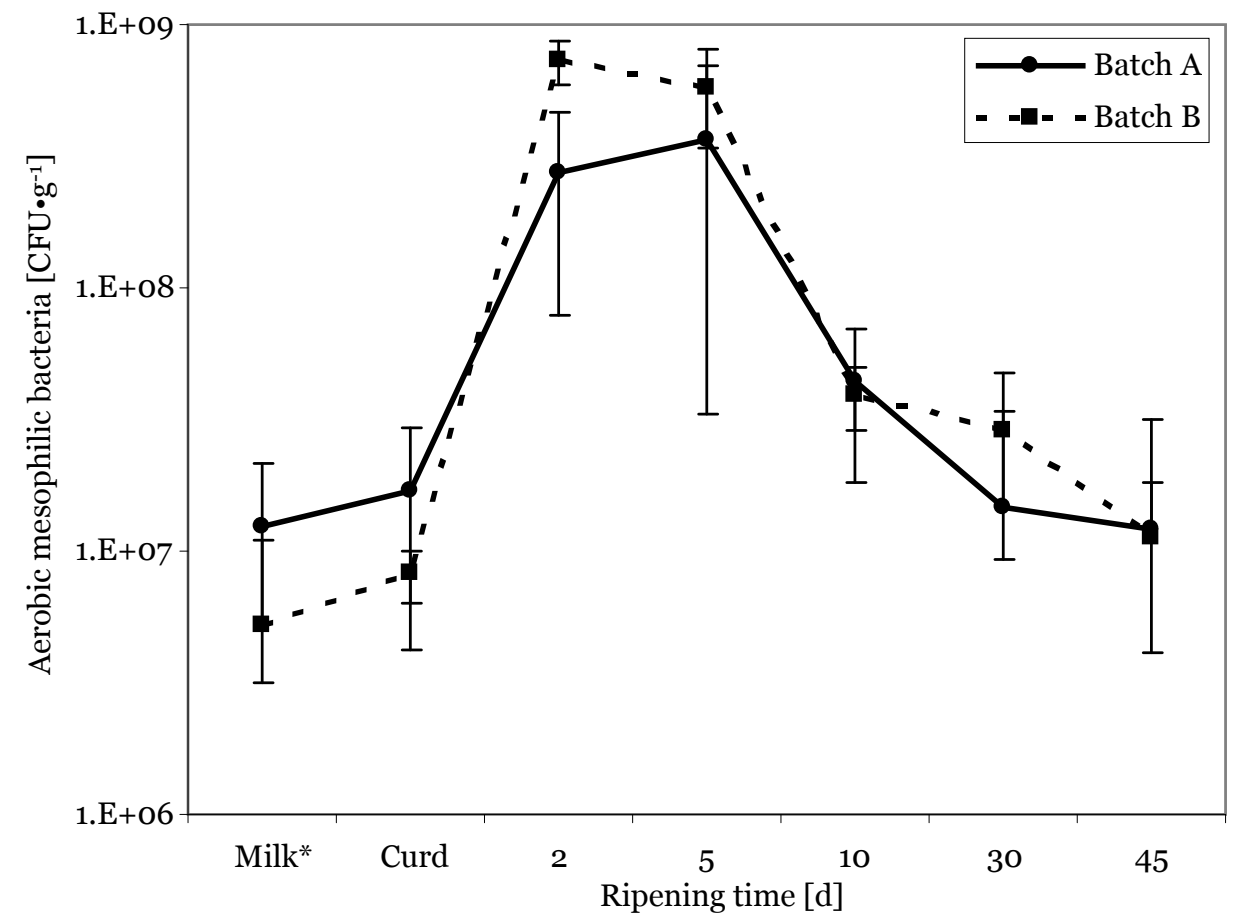

${ }^{*}$ counts are given in colony forming units per milliliter $\left[\mathrm{CFU} \cdot \mathrm{mL}^{-1}\right]$

Figure 1. Changes in counts of aerobic mesophilic bacteria during manufacturing and ripening of beaten cheese from Mariovo region 


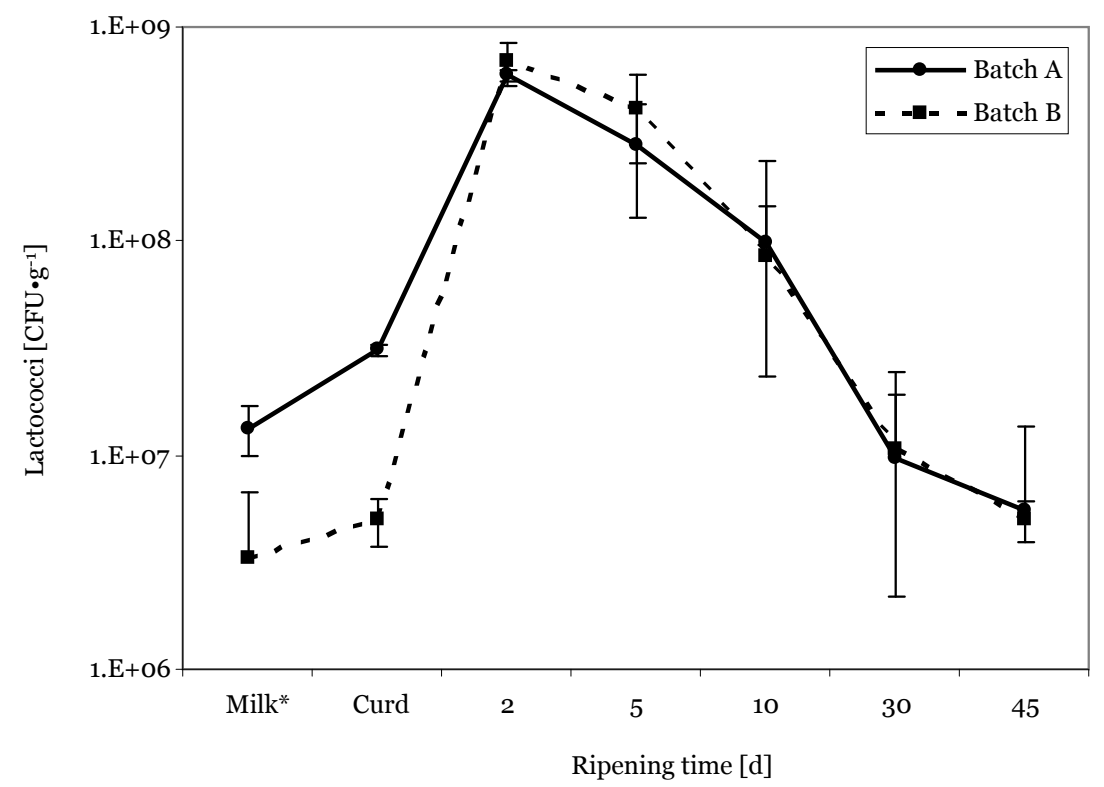

${ }^{*}$ counts are given in colony forming units per milliliter $\left[\mathrm{CFU} \cdot \mathrm{mL}^{-1}\right]$

Figure 2. Changes in counts of presumptive lactococci during manufacturing and ripening of beaten cheese from Mariovo region

al., 2002). In comparison to lactobacilli, presumptive lactococci developed more rapidly in the initial stages of the ripening. Because of their proliferation and active metabolism, lactococci might utilize lactose rapidly (Wouters et al., 2002) and influence the growth of other microbial groups. The counts of presumptive lactococci in milk differed between the batches. Milk used for cheese production in batch A contained more lactococci than batch B (Figure 2). Such differences could be a result of random environmental milk contamination by lactococci, with specific epiphyte microflora of meadow vegetation constituted beneath the climate impact (TerzićVidojević et al., 2009a).

After the curdling, the number of presumptive lactococci increased as a result of their physical entrapment and reproduction. Maximal average values were attained on the $2^{\text {nd }}$ day of ripening, which was in accordance with results obtained during the same stage of ripening in other traditional cheeses as Anevato (Hatzikamari et al., 1999), traditional Italian ewe's milk cheeses (Coda et al. 2006; Di Cagno et al., 2003) and Azerbaijan traditional dairy products (Terzic-Vidojevic at al., 2009). The gradually decrease of cocci LAB was noticed at the $5^{\text {th }}$ day of ripening and was continued until the end of ripening (Fig. 2).

Statistical analyses a negative correlation between $\mathrm{pH}$ and presumptive lactococci $(\mathrm{r}=-0.46$ $p<0.05)$. Several studies on different types of cheese suggested that lactococci might be sensitive to low pH values (Alonso-Calleja et al., 2002; Ferrazza et al., 2004). However, according to the present study the decrease of the $\mathrm{pH}$ values didn't result in the decline of the lactococci number. Such results were probably a consequence of adaptive processes of lactococci to the conditions present in cheese. However the high content of $\mathrm{NaCl}$ and $\mathrm{S} / \mathrm{M}$ in the beaten cheese were the main inhibitory factors that influenced lactococci counts $(\mathrm{NaCl} \mathrm{r}=-0.83$ and for $\mathrm{S} / \mathrm{M} \mathrm{r}=-0.81 ; \mathrm{p}<0.01$ ).

Lactobacilli usually predominate during the late stages of ripening, due to higher tolerance to adverse conditions in the cheese such as low $\mathrm{pH}$ and water content, higher salt content and eventually presence of bacteriocins synthesized by the lactococci (Marino et al., 2003). High count of lactobacilli $\left(10^{9} \mathrm{CFU} \cdot \mathrm{g}^{-1}\right)$ at $2^{\text {nd }}$ day of ripening (Figure 3 ) might be a result of additional contamination by microorganisms present in the air and dairy equipment (Beresford et al., 


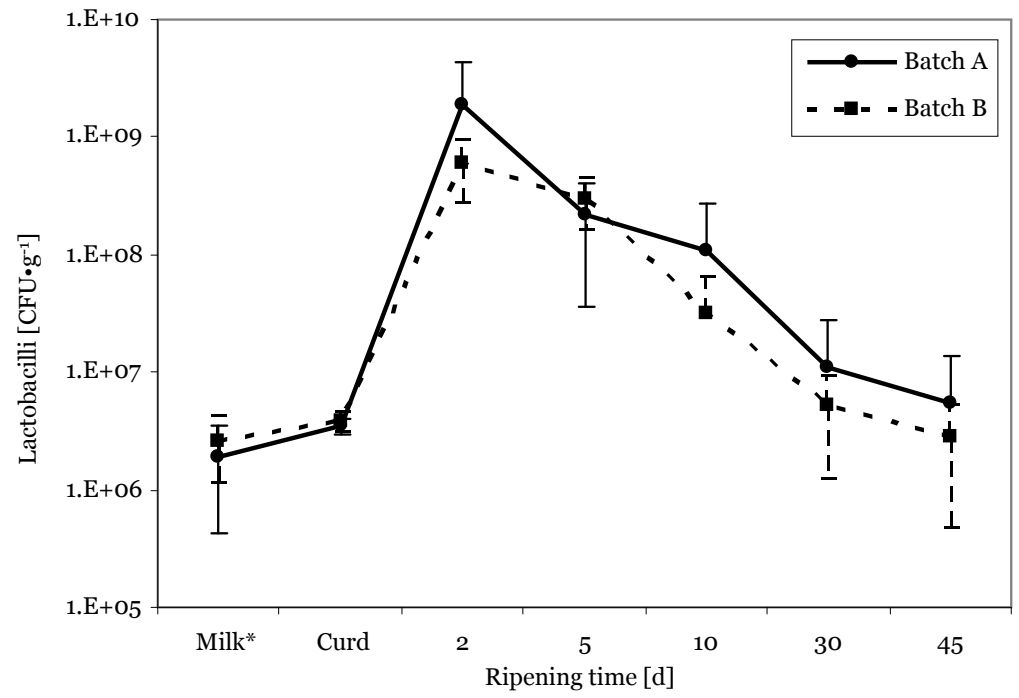

* counts are given in colony forming units per milliliter $\left[\mathrm{CFU} \cdot \mathrm{mL}^{-1}\right]$

Figure 3. Changes in counts of presumptive lactobacilli during manufacturing and ripening of beaten cheese from Mariovo region

2001; Fitzsimons et al., 1999). After 5 days of ripening until the end of the process, the number of lactobacilli showed a constant decline due to the influence of high content of salt, S/M and low water content (Fox et al., 2000; Fontecha et al., 1990). The inhibitory influence of these factors on lactobacilli counts was confirmed by a negative correlation coefficient ( $\mathrm{r}=-0.87$ for $\mathrm{NaCl}$; $\mathrm{r}=-0.85$ for $\mathrm{S} / \mathrm{M}$; $\mathrm{p}<0.01)$. In that manner, the results obtained in the present study were not in correspondence with surveys of Ferrazza et al. (2004) and Arenas et al. (2004). However, latter authors analysed samples of Zamorano and Genestoso cheese and found lower contents of $\mathrm{NaCl}$ and $\mathrm{S} / \mathrm{M}$ in comparison to those found in beaten cheese from Mariovo region. It was noticed that lactobacilli were tolerant to values of $8-10 \% \mathrm{~S} / \mathrm{M}$, while contents (as in case of cheese from Mariovo) over $15 \%$ had inhibitory influence (Fox et al., 2000).

Since Lactobacilli are usually tolerant to low $\mathrm{pH}$, values below 5.5 didn't result in a decrease in their number. Such finding were also confirmed in the present study, where a significant $(\mathrm{p}<0.01)$ negative correlation coefficient between $\mathrm{pH}$ and lactobacilli counts was achieved $(r=-0.58)$. The negative correlation between lactobacilli and $\mathrm{pH}$ seems to corroborate the capacity of lactobacilli to grow at $\mathrm{pH}$ lower than 5 (Alonso-Calleja et al., 2002).

There was a high prevalence of coliform bacteria in raw ewe's milk used for manufacturing of both batches of beaten cheese (Fig. 4). The raw ewe's milk usually contains high counts of coliform bacteria (Sevi et al., 2004) which indicates sanitary conditions during cheese production. Hence, a variable number of coliform bacteria might be a result of stables and maturation room hygiene, but might also indicate hygiene of personnel (Manolopoulou et al., 2003). After the curdling the prevalence of coliform bacteria increased which was more characteristic for batch B of beaten cheese. Beside the physical entrapment of the bacteria as a result of casein deposition, the proliferation of coliform bacteria might be influenced by additional contamination by dairy equipment (Psoni et al., 2003). Coliform bacteria showed similar dynamic pattern as other investigated groups of microorganisms. The highest values were detected on the $2^{\text {nd }}$ day of ripening (Fig. 4). Such results were is in accordance with data from other studies on traditional cheeses (Prodromou et al., 2001; Pešić-Mikulec et al., 2005). Coliforms 


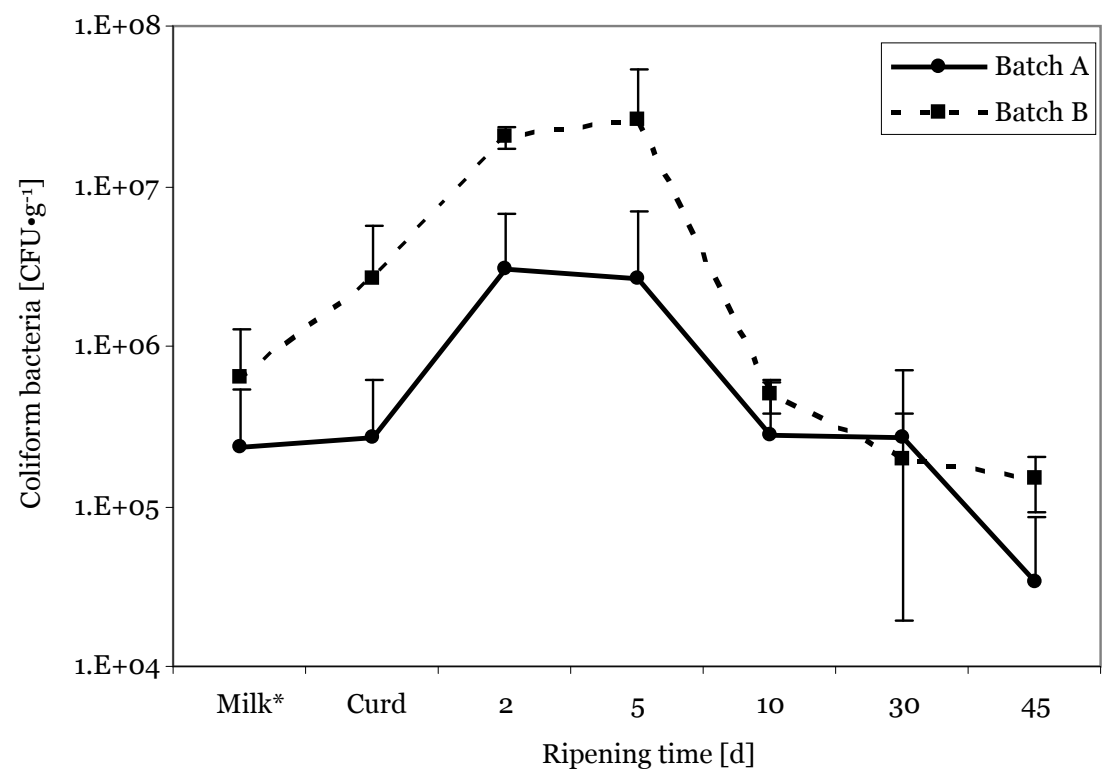

${ }^{*}$ counts are given in colony forming units per milliliter $\left[\mathrm{CFU} \cdot \mathrm{mL}^{-1}\right]$

Figure 4. Changes in counts of coliform bacteria during manufacturing and ripening of beaten cheese from Mariovo region

tend to decline on the $5^{\text {th }}$ day of ripening which was more apparent in batch A. High competitiveness of $\mathrm{LAB}$ over coliforms and high salt content were the main factors that influenced a decrease of the coliforms (Alonso-Calleja et al., 2002; Manolopoulou et al., 2003; Caridi et al., 2003). On the other side, the increase of coliform bacteria on the $5^{\text {th }}$ day of ripening in batch $\mathrm{B}$ might be a result of additional cheese contamination during cutting and dry salting. Both, cutting and dry salting, were performed manually, without specific measures to prevent environmental contamination. Coliform bacteria showed a decline during the ripening in brine (10-45 day of ripening), but in the final product their number was higher when compared to several other studies (Turkoglu et al. 2003; Kamber and Çelik, 2007; Kirdar and Kursun, 2011). Thereby, it must be taken in account that the ambient temperature in maturation room was rather high which might have influenced the high prevalence of coliform bacteria. Additionally, the high initial number of coliforms in milk also had an impact on the abundance of coliforms in the final product (Psoni et al., 2003; Manolopoulou et al., 2003).
It was found that the decrease of $\mathrm{pH}$ did not have a large influence on the growth dynamics of coliforms. However, the main inhibitory impact on coliforms had $\mathrm{NaCl}$ content and $\mathrm{S} / \mathrm{M}$ ratio, which was confirmed by statistical analyses $(r=-0.82, r=-0.76$ respectively; $\mathrm{p}<0.01$ ).

Yeasts are considered as significant part of cheese microflora, especially in later stages of ripening (Corbo et al., 2001). Investigations of ewe's milk beaten cheese showed the presence of yeasts during the whole process, starting from the raw milk to the final product. However, there were differences in the counts between the raw milk from two batches, whereas milk from batch A contained lower initial number of yeasts (Fig. 5). The highest prevalence of yeasts in batch A was noticed after the $2^{\text {nd }}$ day of ripening, while in the batch $B$, the highest numbers occurred at the $5^{\text {th }}$ day of ripening. It must be considered that yeasts usually originate from the environment of the diary plant, as well as from the dairy equipment (Manolopoulou et al., 2003). Yeasts can occur in cheese in higher number during the salting. It was noticed that higher salt content had favorable influence on yeasts and moulds growth (Tarakci et al., 2004). However, the high content of 


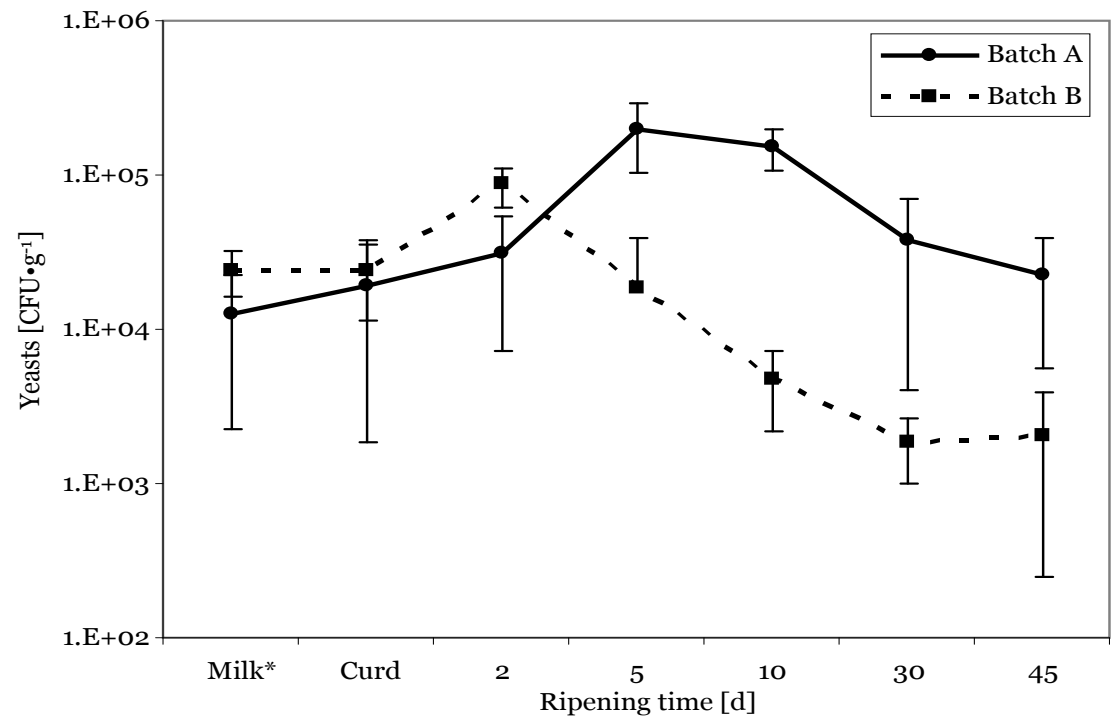

* counts are given in colony forming units per milliliter $\left[\mathrm{CFU} \cdot \mathrm{mL}^{-1}\right]$

Figure 5. Changes in counts of yeasts during manufacturing and ripening of beaten cheese from Mariovo region

$\mathrm{NaCl}$ and $\mathrm{S} / \mathrm{M}$ ratio in the beaten cheese caused a decrease in the yeast number. This was confirmed by a negative coefficient of correlation $(\mathrm{r}=-0.70 \mathrm{p}<0.05$ for $\mathrm{NaCl}$; $\mathrm{r}=-0.76 \mathrm{p}<0.01$ for $\mathrm{S} / \mathrm{M})$. Volken de Souza et al. (2003) noticed that the increase of the cheese matrix compaction reduces the oxygen required for the multiplication of the yeasts, which resulted in decreasing of the yeast counts. The investigations of the beaten cheese showed that the low $\mathrm{pH}$ did not impact the yeast population, since they were able to adapt to adverse conditions. On the other side, yeasts were able to use lactic acid and to increase the $\mathrm{pH}$ value of cheese that was noticed in the final stages of ripening. Similar results were obtained by Turkoglu et al. (2003) and Gerasi et al. (2003). The dynamics of yeasts in beaten cheese from Mariovo was similar to other studies on traditional cheeses (Sevi et al., 2004; Di Cagno et al., 2003).

\section{Lactic acid bacteria present during ripening}

A total of 240 isolates of LAB were identified from all stages of manufacturing and ripening. The prevailing species (35\%) in cheeses from both batches was Lactococcus lactis ssp. lactis found in milk and in early stages of cheese ripening. From all of the isolates, $16.7 \%$ belong to the genus Pediococcus sp. and only $1 \%$ belong to the genus Leuconostoc sp., which were isolated only from the batch A. Lactobacilli were mostly isolated at later stages of ripening. The most prevailing species in cheeses from both batches were Lactobacillus paracasei ssp. paracasei (22.5 $\%)$ and L. plantarum (15.8 \%). The species L. brevis (9.2\%) was isolated during dry salting and brine ripening only from batch $\mathrm{A}$ of beaten cheese.

These investigations indicated a prevalence of mesophilic bacteria in cheese from both batches. Such findings were typical for traditional cheese (Beuvier and Buchin, 2004). The species composition of LAB in beaten cheese is characteristic for brined cheeses produced in the north-eastern Mediterranean countries as well as for countries on Balkan Peninsula (Bintsis and Papademas, 2002).

\section{Conclusion}

This is one of the first studies focusing on traditional cheese produced from ewe's raw milk in Macedonia. The process of manufacture at both farms in Mariovo is old-fashion, without using any modern equipment. The obtained results indicated a high number of all investigated groups of microorganisms in all stages of production, starting from the raw milk to the final product. 
The presence of high counts of aerobic mesophilic bacteria, coliform bacteria and yeasts in milk and cheese during production and ripening demonstrated the poor sanitary and hygienic conditions at both farms. This study implies the necessity of introducing and maintaining a good hygiene practices through the whole process of cheese production in order to obtain a high-quality and safe final product. The isolated species of LAB are essential for characteristic flavour of beaten cheese. It is important to study this autochthonous flora more closely to understand their importance in flavour formation. The study of traditional cheese microflora might contribute to the introduction and preservation of microbial population biodiversity.

\section{Mikrobiološke i kemijske karakteristike tradicionalnog ovčjeg sira iz Mariovske regije}

\section{Sažetak}

Tradicionalni "bijeni" sir proizveden je iz sirovog ovčjeg mlijeka na dvije različite farme locirane $\mathrm{u}$ Mariovskoj regiji (južna Makedonija) tijekom ljetnog razdoblja. U svim ispitivanim grupama utvrđena je visoka zastupljenost mikroorganizama u ovčjem mlije$\mathrm{ku}$ (aerobne mezofilne bakterije 5,22 $\times 10^{6}-1,25 \times 10^{7}$

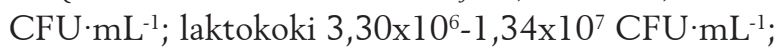
laktobacili $1,93 \times 10^{6}-2,63 \times 10^{6} \mathrm{CFU} \cdot \mathrm{mL}^{-1}$; koliformne bakterije $2,35 \times 10^{5}-6,30 \times 10^{5} \mathrm{CFU} \cdot \mathrm{mL}^{-1}$ i kvasci $\left.1,24 \times 10^{4}-2,40 \times 10^{4} \mathrm{CFU} \cdot \mathrm{mL}^{-1}\right)$. Mliječno kiselinske bakterije prevladavaju tijekom proizvodnje i zrenja ovčjeg sira. Sve ispitivane grupe mikroorganizama dostigle su maksimalne vrijednosti tijekom suhog zrenja, poslije čega se njihova brojnost tijekom soljenja i zrenja u salamuri postupno smanjivala. Ukupno je izolirano 240 izolata iz svih faza proizvodnje i zrenja bijenog sira. Najzastupljenije vrste su bile Lactococcus lactis ssp. lactis (35\%), Pediococcus sp. (16,7\%), Leuconostoc sp. (1 \%), Lactobacillus paracasei ssp. paracasei $(22,5 \%)$, L. plantarum (15,8 \%) i L. brevis $(9,17 \%)$. Poslije 45 . dana zrenja, koncentracija $\mathrm{NaCl}$ iznosila je $(6,1 \pm 0,8 \%$ i $6,6 \pm 0,1 \%)$, sol u vodenoj fazi $(15,6 \pm 1.4 \%$ i $17,3 \pm 0.3 \%)$ u obje varijante sira bila je jako visoka. Glavni faktori koji utječu na zastupljenost mikroorganizama bili su $\mathrm{NaCl}$ i sadržaj soli u vodenoj fazi. Visoki koeficijent korelacije $(p<0,05)$ utvrđen je između ova dva faktora i brojnosti ispitivanih grupa mikroorganizama.

Ključne riječi: bijeni sir, sastav mikroorganizama,
dinamika mikroorganizama,
tradicionalni ovčji sir, Mariovo

\section{References}

1. Alonso-Calleja, C., Carballo, J., Capita, R., Bernardo, A., Garsía-López, M.L. (2002): Changes in the microflora of Valdeteja raw goat's milk cheese throughout manufacturing and ripening. Lebensmittel Wissenschaft und Technologie Journal 35, 222-232.

2. Anonymous (1963): Säuregradbestimmung nach Soxhlet-Henkel (SH). Titratable acidity evaluation with the Soxhlet-Henkel (SH) method. Milchwissenschaft 18,520 .

3. Arenas, R., González, L., Bernardo, A., Fresno, J.M., Tornadijo, M.E. (2004):. Microbiological and physico-chemical changes in Genestoso cheese, a Spanish acid curd variety, throughout ripening. Food Control 15 (4), 271-279. doi: dx.doi.org/10.1016/S0956-7135(03)00067-7

4. Beresford, T., Williams, A. (2004): The microbiology of cheese ripening. In: Cheese: Chemistry, Physics and Microbiology. P.F. Fox, (Ed.), Vol. 1: General Aspects. London: Academic press, 287-317.

5. Beresford. P.T., Fitzsimons, A.N., Brennan, L.N., Cogan, M.T. (2001): Recent advances in cheese microbiology. International Dairy Journal 11, 259-274. doi: dx.doi.org/10.1016/S0958-6946(01)00056-5

6. Beuvier, E., Buchin, S. (2004): Raw milk cheeses. In: Cheese: Chemistry, Physics and Microbiology Fox, P.F., McSweeney, P.H., Cogan, T.M., Guinee T.P. (Ed.), Vol. 1, General Aspects. London: Academic press, 319347.

7. Bintsis, T., Papademas, P. (2002): Microbiological quality of white-brined cheese: a review. International Journal of Dairy Technology 55 (3), 113-120. doi: dx.doi.org/10.1046/j.1471-0307.2002.00054.x

8. Bonetta, S., Coïson, J.D., Barile, D., Bonetta, S., Travaglia, F., Piana, G., Carraro, E., Arlorio, M. (2008): Microbiological and chemical characterization of a typical italian cheese: Ribola di Roccaverano. Journal of Agricultural and Food Chemistry 56, 7223-7230. doi: dx.doi.org/10.1021/jf8000586

9. Caridi, A., Micari, P., Foti, F., Ramondino, D., Sarullo, V. (2003): Ripening and seasonal changes in microbiological and chemical parameters of the artisanal cheese Caprino d'Aspromonte produced from raw or termized goat's milk. Food Microbiology 20, 201-209. doi: dx.doi.org/10.1016/S0740-0020(02)00116-8 
10. Coda, R., Brechany, E., De Angelis, M., De Candia, S., Di Cagno, R., Gobbetti, M. (2006): Comparison of the compositional, microbilogical, biochemical and volatile profile characteristics of nine Italian ewe's milk cheeses. Journal of Dairy Science 89, 4126-4143. doi: dx.doi.org/10.3168/jds.S0022-0302(06)72458-4

11. Corbo, M.R., Albenzio, M., De Angelis, M., Sevi, A., Gobbetti, M. (2001): Microbiological and biochemical properties of Canestrato Pugliese hard cheese supplemented with Bifidobacteria. Journal of Dairy Science 84, 551-561. doi: dx.doi.org/10.3168/jds.S0022-0302(01)74507-9

12. Di Cagno, R., Banks, J., Sheehan, L., Fox, P.F., Brechany, E.Y., Corsetti, A., Gobbetti, M. (2003): Comparison of the microbiological, compositional, biochemical, volatile profile and sensory characteristics of three Italian PDO ewes' milk cheese. International Dairy Journal 13, 961-972. doi: dx.doi.org/10.1016/S0958-6946(03)00145-6

13. Dubrova Mateva, N., Naletoski, Z., Palasevski, B. (2008). Technology and chemical composition of beaten cheese in Republic of Macedonia. Biotechnology and Animal Husbandry 24 (1-2), 139-147. doi: dx.doi.org/10.2298/BAH0802139M

14. Ferrazza, R.E., Fresno, J.M., Ribeiro, J.I., Tornadijo, M.E., Mansur Furtado, M. (2004): Changes in the microbial flora of Zamorano cheese (P.D.O.) by accelerated ripening process. Food Research International 37, 149-155. doi: dx.doi.org/10.1016/j.foodres.2003.08.010

15. Fitzsimons, N.A., Cogan, T.M., Condon, S., Beresford, T. (1999): Phenotipic and genotypic characterization of non-starter lactic acid bacteria in mature Cheddar cheese. Applied and Environmental Microbiology 65 (8), 3418-3426.

16. Fontecha, J., Peláez, C., Juárez, M., Requena, T., Gómez, C. (1990): Biochemical and microbiological characteristics of artisanal hard goat's cheese. Journal of Dairy Science 73, 1150-1157. doi: dx.doi.org/10.3168/jds.S0022-0302(90)78776-0

17. Fox, P.F., Guinee, T.P., Cogan, T.M., McSweeney, P.L.H. (2000): Fundamentals of cheese science. Gaithersburg, Aspen Publishers.

18. Garabal, J.I. (2007): Biodiversity and survival of autochthonous fermented products. International Microbiology $10,1-3$.

19. Gerasi, E., Litopoulou-Tzanetaki, E., Tzanetakis, N. (2003): Microbiological study of Manura, a hard cheese made from raw ovine milk in the Greek island Sifnos. International Journal of Dairy Technology 56 (2), 117-122. doi: dx.doi.org/10.1046/j.1471-0307.2003.00085.x

20. Guinee, T.P., Fox, P.F. (2004): Salt in Cheese: Physical, Chemical and Biological Aspects In: Cheese, Chemistry, Physics and Microbiology. Fox, P.F., McSweeney, P.H., Cogan, T.M., Guinee T.P. (Ed.), Vol. 1: General Aspects. London: Academic press, 207-259.

21. Hatzikamari, M., Litopoulou-Tzanetaki, E., Tzanetakis, N. (1999): Microbiological characteristics of Anevato: a traditional Greek cheese. Journal of Applied Microbiology 87, 595-601. doi: dx.doi.org/10.1046/j.1365-2672.1999.00857.x
22. Holt, J.G., Krieg, N.R., Sneath, N.R., Staley, J.T., Williams, S.T. (1994): Gram-positive cocci, In: Bergey's manual of determinative bacteriology $9^{\text {th }}$ ed. Hensyl, W. R. (ed): London, Williams \& Wilkins, 527-558.

23. ISO 5534:2004, (2004). Cheese and processed cheese-determination of the total solids content (Reference method). Geneva: International Organization for Standardization.

24. Kamber, U., Çelik, T.H. (2007): Some microbiologi$\mathrm{cal}$ and chemical characteristics of Gorcola cheese. The Journal of the University of Yuzuncu Yil, Faculty of Veterinary Medicine 18 (1), 87-92.

25. Kapac-Parkačeva, N., Čižbanovski, T., Lazarevska, D. (1974): The chemical composition and rheological properties of macedonian "Beaten" cheese. Mljekarstvo 24 (4), 74-82.

26. Kirdar, S.S., Kursun, O. (2011): Microflora and pathogen bacteria in traditional Anatolian Canak (Pan) cheese. Journal of Animal and Veterinary Advances 10 (19), 2511-2515. doi: dx.doi.org/10.3923/javaa.2011.2511.2515

27. Kosikowski, F.V., Mistry, V.V. (1997): Analyses. In: Cheese and Fermented Milk Foods. Kosikowski, F.V., Mistry, V.V. (Ed.), Vol. 2: Westport, Connecticut, USA: F.V. Kosikowski, L.L.C., 208-264.

28. Levkov, V., Kakurinov, V. (2011): Microbiological properties of artisanal cheese (Bieno sirenje). Journal of $\mathrm{Hy}$ gienic Engineering and Design 1, 325-329.

29. Manolopoulou, E., Sarantinopoulos, P., Zoidou, E., Aktypis, A., Moschopoulou, E., Kandarakis, I.G., Anifantakis, E.M. (2003): Evolution of microbial populations during traditional Feta cheese manufacture and ripening. International Journal of Food Microbiology 82, 153-161 doi: dx.doi.org/10.1016/S0168-1605(02)00258-1

30. Marino, M., Maifreni, M., Rondinini, G. (2003): Microbiological characterization of artisanal Montasio cheese: analysis of its indigenous lactic acid bacteria. FEMS Microbiology Letters 229, 133-140. doi: dx.doi.org/10.1016/S0378-1097(03)00816-4

31. Matevski, V., Kostadinovski, M. (1998): Biserrulo-Scleranthetum Dichotomae Matevski et Kostadinovski ass. nova in highland pastures in Republic of Macedonia. Annual Biology 51, 25-35.

32. Micari, P., Sarullo, V., Sidari, R., Caridi, A. (2007): Physico-chemical and higienic characteristics of the calabrian raw milk cheese, Caprino d'Aspromonte. Turkish Journal of Veterinary and Animal Science 31 (1), 55-60.

33. Nikolaou, E., Tzanetakis, N., Litopoulou-Tzanetaki, E., Robinson, R.K. (2002): Changes in the microbiological and chemical characteristics of an artisanal, low-fat cheese made from raw ovine milk during ripening. International Journal of Dairy Technology 55 (1), 12-17. doi: dx.doi.org/10.1046/j.1471-0307.2002.00032.x

34. Özdemir, S., Yangilar, F., Ozdemir, C. (2010): Determination of microbiological characteristics of Turkish Karin kaymagi cheeses packaged indifferent materials. African Journal of Microbiology Research 4 (9), 716-721. 
35. Pešić-Mikulec, D., Jovanović, L. (2005): Microbiological study of fresh white cheese (A Serbian craft variety). Applied Ecology and Environmental Research 4 (1), 129134.

36. Prodromou, K., Thasitou, P., Haritonidou, E., Tzanetakis, N., Litopoulou-Tzanetaki, E. (2001): Microbiology of Orinotyri, a ewe's milk cheese from Greek mountains. Food Microbiology 18, 319-328. doi: dx.doi.org/10.1006/fmic.2001.0403

37. Psoni, L., Tzanetakis, N., Litopoulou-Tzanetaki, E. (2003): Microbiological characteristics of Batzos, a traditional Greek cheese from raw goat's milk. Food Microbiology 20, 575-582. doi: dx.doi.org/10.1016/S0740-0020(02)00153-3

38. Radulović, Z., Miočinović, J., Pudja, P., Barać, M., Miloradović, Z., Paunović, D., Obradović, D. (2011): The application of autochthonous lactic acid bacteria in white brined cheese production. Mlijekarstvo 61 (1), 15-25.

39. Sevi, A., Albenzio, M., Marino, R., Santillo, A., Muscio, A. (2004): Effects of lambing season and stage of lactation on ewe milk quality. Small Ruminant Research 51, 251-259. doi: dx.doi.org/10.1016/S0921-4488(03)00196-2

40. Skeie, S., Ardö, Y. (2000): Influence from raw milk flora on cheese ripening studied by different treatments of milk to model cheese. Lebensmittel Wissenschaft und Technologie Journal 33, 499-505.

41. Talevski, G., Čobanova-Vasilevska, R., Srbinovska, S., Sireta, Z. (2009): Quality of the sheep milk as a raw material in dairy industry of Macedonia. Biotechnology and Animal Husbandry 25, (5-6), 971-977.

42. Tarakci, Z., Sagun, E., Sancak, H., Durmaz, H. (2004): The effect of salt concentration on some characteristics in Herby cheese. PakistanJournalof Nutrition 3 (4), 232-236. doi: dx.doi.org/10.3923/pjn.2004.232.236

43. Terzic-Vidojevic, A., Vukasinovic, M., Veljovic, K., Ostojic, M., Topisirovic, Lj. (2007): Characterization of microflora in homemade semi-hard white Zlatar Cheese. International Journal of Food Microbiology 114, 36-42. doi: dx.doi.org/10.1016/j.ijfoodmicro.2006.10.038
44. Terzic-Vidojevic, A., Veljovic, K., Tolinacki, M., Lozo, J., Begovic, J., Gulahmadov, S., Kuliev, A.A., Delgalarrondo, M., Chobert, J.M., Haertlé, T., Topisirovic, Lj. (2009): Phenotypic and genotypic characterization of lactic acid bacteria isolated from Azerbaijani traditional dairy products. African Journal of Biotechnology 8 (11), 2576-2588.

45. Terzić-Vidojević, A., Nikolić, M., Veljović, K., Tolinački, M., Busarčević, M., Topisirović, Lj. (2009a): Analysis of the lactic acid bacteria microflora in traditional caucasus cow's milk cheeses. Archiva of Biological Science Belgrade 61 (3), 395-406. doi: dx.doi.org/10.2298/ABS0903395T

46. Turkoglu, H., Ceylan, Z.G., Dayisoylu, K.S. (2003): The microbiological and chemical quality of Orgu cheese produced in Turkey. Pakistan Journal of Nutrition 2 (2), 92-94. doi: dx.doi.org/10.3923/pjn.2003.92.94

47. Volken de Souza, C.F., Rosa, T.D., Ayub, M.A.Z. (2003): Changes in the microbiological and physicochemical characteristics of Serrano cheese during manufacture and ripening. Brazilian Journal of Microbiology 34, 260266.

48. Williams, A.G., Choi, S.C., Banks, J.M. (2002): Variability of the species and strain phenotype composition of the non-starter lactic acid bacterial population of cheddar cheese manufactured in a commercial creamery. Food Research 35, 483-493. doi: dx.doi.org/10.1016/S0963-9969(01)00147-8

49. Wouters, J.T.M., Ayad, E.H.E., Hugenholtz, J., Smit, G. (2002): Microbes from raw milk for fermented dairy products. International Dairy Journal 12, 91-109. doi: dx.doi.org/10.1016/S0958-6946(01)00151-0 